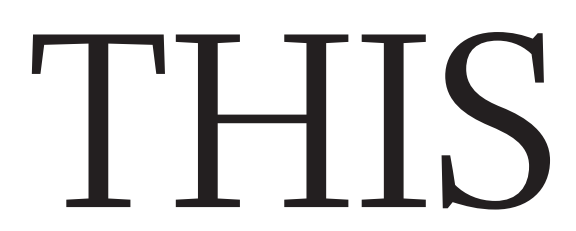

EDITORIALS
WORLD VIEW Go on, find and unleash your hidden capitalist $\mathbf{p} \mathbf{1 3 3}$

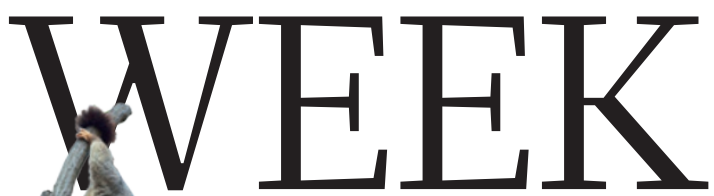

TANGLED WEB The

problems of invasive species control p.135
9/11 LEgacy The lingering

health impacts of the New

York attacks p.136

\title{
A very Turkish coup
}

\section{Scientists around the world should protest efforts by the government of Turkey to erode academic autonomy. And the wider world should note the threat to democracy.}

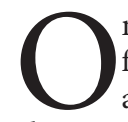
$\mathrm{n}$ the eve of a week-long holiday to celebrate the end of the fasting period of Ramadan, the Turkish government executed an extraordinary scientific coup. On 27 August, it issued a decree with immediate effect, giving itself tighter control of Turkey's two main scientific organizations: the funding agency TÜBİTAK and the Turkish Academy of Sciences (TÜBA), the governance of which is now so altered that it can no longer be considered an academy at all.

The move has startled and appalled Turkish scientists. It should also sound an alarm bell throughout Turkish society. The government of Prime Minister Recep Tayyip Erdoğan is also taking greater control of other sectors through a series of decrees requiring no parliamentary debate. In the past few weeks, for example, it has brought under direct government supervision ten previously independent regulatory bodies, including some financial institutions and media regulators, as well as the Natural and Cultural Assets Conservation Committee, which determines environmentally protected zones.

TÜBİTAK, the Scientific and Technological Research Council of Turkey, was already close to the government. Now that relationship has been reinforced and institutionalized. A triumvirate of president, prime minister and science minister will appoint some members of TÜBİTAK's decision-making scientific board, and nominate its president and two vice-presidents. The triumvirate lost no time, and on 30 August it replaced the incumbent president with electrical engineer Yücel Altunbaşak, rector of the TOBB University of Economics and Technology in Ankara. The government will also have much more influence over the choice of other board members.

At least TÜBİTAK is a state agency. It matters much more that the government is taking over TÜBA, which was founded in 1993 as an autonomous organization under the patronage of the prime minister. It has nearly 82 full members (from a total membership of 140) and has been doing all the things academies should do - including offering scientific advice to the government, publishing reports, and giving scholarships and awards. TÜBA has also been active in international organizations of academies such as the InterAcademy Panel, ALLEA (the organization of European academies) and the Association of Academies of Sciences in Asia (AASA).

A June decree transferred TÜBA to the Ministry of Science, Industry and Technology. The current decree raises the number of full members to 150 . One-third will be appointed by the government and one-third by YÖK, the Higher Education Council, most of whose members are in turn appointed by the government or president.

The current decree also says that TÜBA will be involved in creating a series of basic-research institutes. What this means is unclear, because no budget for institutes has been announced, and the government has recently effectively closed down the only non-university basic-research institute, the Feza Gürsey Institute (see Nature 477, $33 ; 2011)$. If the intention to create basic-research institutes were sincere, it would be a welcome counterbalance to this government's naive encouragement of only applied research. But the academy would not be the right place for them. The Soviet model of linking institutes to national academies has been discredited, and post-Soviet countries quickly moved to separate the entities.

The government has made a big mistake in interfering with TÜBA’s membership. Every democratic country requires an independent academy to provide independent scientific advice. But then this gov-
"The ernment shows little respect for expert advice. It

takeover did not consult the scientific community (or even its political opposition) on the wisdom of the move - just as it didn't consult when it created challenged." a catastrophic law last year (see Nature 464, 478; 2010) intended to regulate the use of genetically modified plants, but which unintentionally crippled all molecular biology research. (Scientists continue to work by ignoring the law.)

The academy is appealing to President Abdullah Gül to reverse the decree. Academies all around the world should write to Gül too. Many TÜBA members say that if this approach fails, they will resign as soon as the government's first appointments are made. They would be right to do so. At this point, international organizations of academies should formally derecognize TÜBA on the grounds that it no longer meets the membership criteria of self-governance and appointment solely on scientific merit.

Scientists around the globe need to respond to this. Although the fate of one academy may seem small on the world stage, it is symbolic of a general anti-democratic shift in a country that is pivotal in world politics. The takeover must be challenged.

\section{Heavy weather}

\section{Severe storms make the public think of climate change. Scientists must work to evaluate the link.}

E xtreme weather makes news, as was demonstrated last month by the blanket coverage of the devastation caused to the east coast of the United States by Hurricane Irene. But was the prominence of the story a feature of modern media hype in a rolling-news world? Hardly. According to a New York Times analysis, when Hurricane Andrew made landfall in Florida in 1992 and killed 22 people, it received twice the traditional news coverage that Irene did.

What is new is that coverage of extreme weather is now often accompanied by a question: is this a consequence of climate change? This question was raised frequently after Hurricane Katrina smashed through New Orleans in 2005. Most climate scientists responded 